\title{
A real-time RT-PCR for detection of clade 1 and 2 H5N1 Influenza A virus using Locked Nucleic Acid (LNA) TaqMan probes
}

\author{
Thanh Tran Tan ${ }^{1 *}$, Hana Apsari Pawestri ${ }^{2}$, Ngoc Nghiem My ${ }^{3}$, Hien Vo Minh ${ }^{3}$, Harun Syahrial ${ }^{2}$, Trung Nguyen Vu ${ }^{4}$, \\ H Rogier van Doorn ${ }^{1,6}$, Heiman FL Wertheim ${ }^{5,6}$, Chau Nguyen Van Vinh ${ }^{3}$, Ha Do Quang ${ }^{1}$, Jeremy J Farrar ${ }^{1,6}$, \\ Hien Tran Tinh ${ }^{3}$, Endang R Sedyaningsih², Menno D de Jong ${ }^{1,6,7}$
}

\begin{abstract}
Background: The emergence and co-circulation of two different clades (clade 1 and 2) of H5N1 influenza viruses in Vietnam necessitates the availability of a diagnostic assay that can detect both variants.

Results: We developed a single real-time RT-PCR assay for detection of both clades of H5N1 viruses, directly from clinical specimens, using locked nucleic acid TaqMan probes. Primers and probe used in this assay were designed based on a highly conserved region in the HA gene of H5N1 viruses. The analytical sensitivity of the assay was < 0.5 PFU and 10 - 100 ssDNA plasmid copies. A total of 106 clinical samples (58 from patients infected with clade 1 , 2.1 or $2.3 \mathrm{H} 5 \mathrm{~N} 1$ viruses and 48 from uninfected or seasonal influenza A virus-infected individuals) were tested by the assay. The assay showed $97 \%$ concordance with initial diagnostics for $\mathrm{H} 5$ influenza virus infection with a specificity of $100 \%$.
\end{abstract}

Conclusions: This assay is a useful tool for diagnosis of H5N1 virus infections in regions where different genetic clades are co-circulating.

\section{Background}

Highly pathogenic avian influenza A (H5N1) viruses cause sporadic infections in humans, and are associated with severe respiratory disease with a mortality of about $60 \%$ [1]. Since the re-emergence of human H5N1 influenza virus infections in January 2003 [2], 436 human cases have been documented in 15 countries in Asia, Africa, and Europe [1]. Genetic studies have revealed that most of the viruses isolated from humans and poultry belong to genotype $\mathrm{Z}[3,4]$. The worldwide distribution of this genotype has resulted in the establishment of at least two genetically and geographically distinct clades: clade 1 and 2 [5]. Clade $1 \mathrm{H} 5 \mathrm{~N} 1$ viruses have been isolated from poultry and humans in Vietnam, Thailand, and Cambodia, and from poultry in Laos and Malaysia [6-8]. Clade 2 viruses have a larger genetic diversity and are divided into 5 sub-clades (2.1 to 2.5) [9]. Clade 2.1

\footnotetext{
* Correspondence: thanhtt@oucru.org

'Oxford University Clinical Research Unit, Hospital for Tropical Diseases, 190 Ben Ham Tu, Dist 05, Ho Chi Minh City, Viet Nam
}

viruses have been found only in Indonesia, in poultry and humans [6]. Clade 2.2 viruses have caused poultry outbreaks and human infections in the Middle East, Africa, and Europe [1]. Clade 2.3 viruses are further divided into four sub-clades (2.3.1 to 2.3.4) [9]. Recently, clade 2.3.4 viruses have become predominant in China and have also been reported in Hong Kong, Laos, Malaysia, Thailand, and North-Vietnam $[10,11]$. In Vietnam, clades 1 and 2.3.4 co-circulate among poultry and have both caused human infections $[11,12]$.

The circulation of more than one virus clade poses a challenge for laboratory diagnostics, since methods for detection of H5N1 infection usually rely on clade specific amplification of the $H A$ gene [13-15]. Although rapid antigen tests, virus isolation, and serological tests can be used to diagnose $\mathrm{H} 5 \mathrm{~N} 1$ infection across all clades, these methods have limited use for routine diagnostics because of the inability to subtype, the low sensitivity, and the requirement of biosafety level 3 laboratory facilities. The accepted reference method for diagnosis of H5N1 infection is real-time RT-PCR (rRT-PCR) [16]. Compared to

C Biomed Central

(c) 2010 Tan et al; licensee BioMed Central Ltd. This is an Open Access article distributed under the terms of the Creative Commons Attribution License (http://creativecommons.org/licenses/by/2.0), which permits unrestricted use, distribution, and reproduction in any medium, provided the original work is properly cited. 
conventional RT-PCR, rRT-PCR has a smaller risk of cross-contamination, higher sensitivity and specificity, and shorter per sample laboratory turnaround time. Several rRT-PCR assays for H5N1 detection have been described [15,17-20], but only two of them have been specifically designed for the detection of both clades $[19,20]$. In addition, clinical evaluation has not been performed for most of these assays [15,18-20].

Recently, the locked nucleic acid (LNA) technology has been integrated into real-time PCR, enabling a more flexible primer and probe design and improving amplification efficiency [21-23]. In this study, we describe the use and evaluation of an LNA TaqMan rRT-PCR for detection of clade 1 and $2 \mathrm{H} 5 \mathrm{~N} 1$ viruses in a large number of clinical specimens $(n=58)$.

The assay described here has been established within the laboratories of the South East Asia Infectious Disease Clinical Research Network [24] to serve as a supplementary diagnostic test in addition to the FDA approved USCDC assay [25] for Influenza virus infection and $\mathrm{H} 5 \mathrm{~N} 1$ subtyping.

\section{Results}

\section{Analytical sensitivity and specificity}

The analytical sensitivity of our LNA Taqman rRT-PCR for the detection of the $H A$ gene of H5N1 was $<0.5$ PFU of virus and 10 copies of ssDNA plasmids. No fluorescence was detected when analyzing human seasonal H1N1 $(\mathrm{n}=4)$ and H3N2 $(\mathrm{n}=5)$ virus isolates and non-H5 avian viruses $(\mathrm{n}=5)$, indicating a high specificity for influenza A viruses of subtype $\mathrm{H} 5$.

\section{Evaluation of sensitivity and specificity in clinical specimens}

The sensitivity of the assay was clinically evaluated in 58 human specimens, previously confirmed to contain clade 1 , clade 2.1 , or clade $2.3 \mathrm{H} 5 \mathrm{~N} 1$ virus by virus isolation and/or H5N1 specific RT-PCRs $[25,26]$ and sequencing (our unpublished data). Our assay detected H5 virus in 56 of these samples (97\%). The sensitivity was $100 \%$ for clade 1 and clade 2.3 , and $92 \%$ for clade 2.1 (Table 1).

Table 1 H5N1 clinical samples and rRT-PCR results

\begin{tabular}{lcccccccc}
\hline $\begin{array}{l}\text { Samples/virus } \\
\text { clade }\end{array}$ & NS & TS & TA & Plas & PF & Stool & Total & $\begin{array}{c}\text { rRT-PCR } \\
\text { positive }\end{array}$ \\
\hline Clade 1 & 2 & 7 & 1 & 0 & 0 & 0 & 10 & 10 \\
\hline Clade 2.1 & 7 & 17 & 1 & 0 & 0 & 0 & 25 & 23 \\
\hline Clade 2.3 & 5 & 7 & 6 & 2 & 2 & 1 & 23 & 23 \\
\hline Total & 14 & 31 & 8 & 2 & 2 & 1 & 58 & 56 \\
\hline rRT-PCR positive & 13 & 30 & 8 & 2 & 2 & 1 & 56 &
\end{tabular}

NS = Nasal swab; TS = Throat swab; TA = Tracheal aspirate; Plas = Plasma; PF $=$ Pleural fluid
The specificity of the assay in clinical specimens was assessed by analyzing influenza A $\mathrm{H} 1$ or $\mathrm{H} 3$ positive samples $(\mathrm{n}=19)$ and influenza negative $(\mathrm{n}=29)$ respiratory samples. All of these samples were negative indicating $100 \%$ specificity.

\section{Discussion}

Recent evidence of co-circulation of clade 1 and clade 2 H5N1 viruses in South East Asia has highlighted the need for RT-PCR assays that allow detection of both genetic clades. We developed a single step rRT-PCR assay using an LNA TaqMan probe for direct detection in clinical samples of $H A$ genes from both clades of H5N1 viruses. This assay was shown to be sensitive, specific, and rapid (approximately 3.5 hours after RNA extraction).

The primers and probe used in this study were designed to target a highly conserved region in the $H A$ gene of $\mathrm{H} 5 \mathrm{~N} 1$ viruses; to ensure amplification of both clade 1 and 2 RNA, one and two degenerated bases were incorporated into the forward and reverse primers, respectively. As the binding efficiency of the original TaqMan probe was inadequate, LNA residues were incorporated that result in a tighter crosslink than normal nucleotides. Incorporation of LNA residues has no consequences for PCR conditions [27] but is a practical way to improve probe-binding efficiency [28].

The assay was shown to be sensitive, detecting 10 copies of ssDNA plasmid, and less than 0.5 PFU of $\mathrm{H} 5 \mathrm{~N} 1$ viruses per reaction, and specific for the detection of influenza A of subtype $\mathrm{H} 5$. The $H A$ gene of clades 1 , 2.1 , and 2.3 was amplified from both virus isolates and human clinical specimens. Cross-reaction with virus isolates from other influenza A subtypes was not observed, and no positive results were obtained when analyzing 48 clinical samples from patients with either seasonal influenza or non-influenza respiratory illness.

Clinical evaluation was performed on 58 stored clinical specimens from 39 patients infected with either clade 1, 2.1 or 2.3 viruses and showed high concordance when compared to initial diagnostic RT-PCR and/or cell culture results. To our knowledge, the number of $\mathrm{H} 5$ positive clinical specimens used in this study is larger than in any other previously published assays [17].

Our assay has not been evaluated in clade $2.2 \mathrm{H} 5 \mathrm{~N} 1$ viruses and clinical specimens. However, in silico analysis of clade 2.2 viruses showed that the primers and probe used this assay would hybridize sufficiently with viruses of this sub-clade to allow amplification (data not shown).

Our assay failed to detect virus in a nasal swab and a throat swab (Table 1). This may be due to RNA degradation during long-term storage and multiple freezethaw cycles. 


\section{Conclusions}

We have developed a highly sensitive and specific rRTPCR assay for the detection of H5N1 influenza A virus of both clade 1 and 2 directly in clinical specimens, and evaluated it with a large number clinical samples. Using this assay, reliable diagnostic results can be obtained in a few hours, thus enabling timely clinical management and outbreak control.

\section{Methods}

\section{Cell-lines and isolates}

For sensitivity and specificity analyses, the following virus isolates were used: 12 clade 1 human $\mathrm{H} 5 \mathrm{~N} 1$ viruses, isolated from patients admitted to the Hospital for Tropical Diseases, Ho Chi Minh City, Viet Nam in 2004 and 2005 [29]; 4 clade 2.3.4 H5N1 viruses isolated from patients admitted to the National Institute of Infectious and Tropical Diseases, Ha Noi, Vietnam in 2007 and 2008; 1 human clade $2.1 \mathrm{H} 5 \mathrm{~N} 1$ isolate (A/ Indonesia/5/2005(H5N1)), kindly provided by The National Institute of Infectious Diseases, Tokyo, Japan; 9 human influenza A viruses of subtype H1N1 $(\mathrm{n}=4)$ and H3N2 $(n=5)$, isolated from patients with seasonal influenza from Dong Thap Province, Vietnam, in 2006; and 7 avian influenza viruses of subtypes $\mathrm{H} 3(\mathrm{n}=1), \mathrm{H} 4$ $(\mathrm{n}=3), \mathrm{H} 5(\mathrm{n}=2)$, and H6 $(\mathrm{n}=1)$, isolated from poultry in 2006 in Ho Chi Minh City, and the southern Vietnamese provinces of Vinh Long, and Dong Thap.

All viruses were cultured in Madin Darby Canine Kidney cells (ECACC, Wiltshire, UK) and were subtyped using previously described methods $[26,30]$.

\section{Clinical samples}

Fifty-eight clinical samples from 39 H5N1-infected patients were used in this study (Table 1), including nasal swabs $(\mathrm{n}=14)$, throat swabs $(\mathrm{n}=31)$, nasopharyngeal aspirates $(n=8)$, stools $(n=1)$, plasma $(n=2)$, and pleural fluids $(n=2)$. Swabs were collected in viral transport medium and stored at $-80^{\circ} \mathrm{C}$. Initial diagnoses in these patients were made independently in Jakarta, Ha Noi, and Ho Chi Minh City by RT-PCR and/or virus isolation using previously described methods $[26,25]$. The samples were collected from patients with H5N1 infection in Indonesia (clade 2.1; 25 specimens from 25 patients) and Vietnam (clade 1; 10 specimens from 10 patients; clade 2.3.4: 23 specimens from 4 patients) between 2004 and 2008 (Table 1).

Nineteen throat swab samples from 19 patients with seasonal influenza (seasonal H1N1: $\mathrm{n}=10$; H3N2: $\mathrm{n}=$ 9), confirmed by conventional RT-PCRs and/or virus isolation as described previously [26], and 29 throat swab samples from 29 patients with non-influenza respiratory illness admitted to the Hospital for Tropical
Diseases Ho Chi Minh City during the H5N1 outbreaks of 2004 - 2005 were also used in this study.

All laboratory analyses in specimens from Indonesian patients for this study were performed at the National Institute of Health Research and Development, Ministry of Health, Jakarta, Indonesia; analyses of specimens from Vietnamese patients were done at the Hospital for Tropical Diseases, Ho Chi Minh City, Vietnam.

\section{Ethical approval}

Clinical specimens from H5N1 patients in Ho Chi Minh City and negative control specimens were obtained as part of studies on $\mathrm{H} 5 \mathrm{~N} 1$ and respiratory infections that were approved by the institutional review board of the Hospital for Tropical Diseases, Ho Chi Minh City, and the Oxford Tropical Research Ethical Committee. Informed consent was obtained from all participating patients or their parents or legal guardians.

The clinical specimens from Indonesian patients and from patients from $\mathrm{Ha}$ Noi were obtained by health care providers from suspected $\mathrm{H} 5 \mathrm{~N} 1$ cases as part of the national procedures for Avian Influenza case investigation which were exempted from review by the institutional review boards.

\section{RNA extraction}

Viral RNA was extracted from $140 \mu$ of clinical samples or from $50 \mu \mathrm{l}$ of culture supernatant and eluted in $60 \mu \mathrm{l}$ elution buffer using QIAamp Viral RNA Mini kit (Qiagen, West Sussex, UK) according to the manufacturer's instructions.

\section{Primer and probe design}

Nucleotide sequences of all available full length $H A$ genes of $\mathrm{H} 5 \mathrm{~N} 1$ viruses $(\mathrm{N}=313)$ were retrieved from Influenza Virus Resource [31] and were aligned using BioEdit version 7.0.1 (Ibis Biosciences, Carlsbad, CA, USA). Primers and probe were designed using Primer Express version 2.0 (Applied Biosystems Inc., Foster City, CA, USA). The probe was further modified using LNA residues. Primers and probes (Table 2) were synthesized by Sigma-Proligo, Singapore.

Table 2 Primers and probe used in this study

\begin{tabular}{lll}
\hline Name & Sequence $^{\mathbf{a}}$ & Nucleotide $^{\mathbf{b}}$ \\
\hline Sense & 5'-TTGGTTACCATGCAAACAAYT-3' $^{\prime}$ & 91-111 \\
\hline Antisense & 5'-TRTCTTGGGCRTGTGTAACA-3 & 152-171 \\
\hline Probe & $\begin{array}{l}\text { 5'-FAM-CAGGTTGACACAATAATGGAAAAG- } \\
\text { BHQ3-3' }\end{array}$ & 119-143 \\
\hline
\end{tabular}

${ }^{a} \mathrm{Y}=\mathrm{T}$ or $\mathrm{C}, \mathrm{R}=\mathrm{A}$ or $\mathrm{G}$. LNA residues in the probe are indicated in bold. $5^{\prime}$ $\mathrm{FAM}=5^{\prime}$ - carboxyfluorescein, BHQ = Black Hole Quencher. ${ }^{\mathrm{b}}$ The position in the $H A$ gene is indicated. 


\section{Determination of sensitivity}

For determination of analytical sensitivity, a representative clade 1 (strain A/Vietnam/CL115/2005(H5N1)) was titrated in MDCK cells, and serial dilutions at concentrations of $10^{4}-10^{-2} \mathrm{PFU} / \mu \mathrm{l}$ were made. From each resulting dilution, viral RNA was extracted and subjected to rRT-PCR.

In addition, sensitivity analyses were performed as follows: PCR products from amplification of the $H A$ gene of A/Vietnam/CL115/2005(H5N1) were purified using the QIAquick ${ }^{\circledR}$ PCR purification kit (Qiagen), and were cloned into pCR2.1-TOPO plasmid, and were then used for transformation of E. coli TOP 10 cells (Invitrogen, Carlsbad, CA, USA). The plasmids derived from a single bacterial colony were sequenced using CEQ Dye Terminator Cycle Sequencing Kit (Beckman Coulter, Fullerton, CA, USA). Selected clones were propagated in liquid LB medium according to the manufacturer's instructions and plasmids were purified using QIAprep $^{\circ}$ Miniprep Kit (Qiagen). After linearization using XhoI (New England Biolabs, Ipswich, UK), DNA concentration was determined spectrophotometrically (NanoDrop 1000, Thermo Scientific, Wilmington, DE, USA). The plasmids were then diluted tenfold in TE $\left(10^{5}-10^{-2}\right.$ copies/ $\mu \mathrm{l}$ ) and were used in analytical sensitivity tests.

All experiments were done in duplicate.

\section{Real-time RT-PCR}

Real-time RT-PCR was performed using iScript ${ }^{\text {ma }}$ OneStep RT-PCR Kit Probes in Chromo 4 real time PCR machines (Bio-Rad, Hercules, CA, USA). The reaction was conducted in a total volume of $25 \mu \mathrm{l}$ containing $12.5 \mu \mathrm{l}$ of $2 \times$ RT-PCR Reaction Mix, $400 \mathrm{nM}$ of each primer, $120 \mathrm{nM}$ of probe, $0.5 \mu \mathrm{l}$ of iScript Reverse Transcriptase, and $5 \mu \mathrm{l}$ of template. Optimized rRT-PCR conditions were as follows: one cycle of $50^{\circ} \mathrm{C}$ for 15 minutes, followed by 5 minutes at $95^{\circ} \mathrm{C}$, and 45 cycles of 15 seconds at $95^{\circ} \mathrm{C}$ and 1 minute at $53^{\circ} \mathrm{C}$.

\section{Acknowledgements}

We would like to thank Dr Triono Soendoro from the National Institute of Health Research and Development, Ministry of Health, Jakarta, Indonesia for his support for this work, and Dr Maciej Boni from the Oxford University Clinical Research Unit, Hospital for Tropical Diseases, 190 Ben Ham Tu, Dist 05, Ho Chi Minh City, Viet Nam for critical review of the manuscript.

\footnotetext{
Author details

'Oxford University Clinical Research Unit, Hospital for Tropical Diseases, 190 Ben Ham Tu, Dist 05, Ho Chi Minh City, Viet Nam. ${ }^{2}$ National Institute of Health Research and Development, Percetakan Negara no. 29, Jakarta 10560, Indonesia. ${ }^{3}$ Hospital for Tropical Diseases, 190 Ben Ham Tu, Dist 05, Ho Chi Minh City, Viet Nam. ${ }^{4}$ National Institute of Infectious and Tropical Diseases, Ha Noi, Viet Nam. ${ }^{5}$ Oxford University Clinical Research Unit - The National Institute of Infectious and Tropical Diseases, Ha Noi, Viet Nam. ${ }^{6}$ Centre for Tropical Medicine, Nuffield Department of Clinical Medicine, University of Oxford, Centre for Clinical Vaccinology and Tropical Medicine, Oxford, UK. ${ }^{7}$ Department of Medical Microbiology, Academic Medical Center, University of Amsterdam, Amsterdam, The Netherlands.
}

\section{Authors' contributions}

TाT: designed the study, did laboratory testing, analysed the test results, and drafted the manuscript.

HAP, NNM, HVM, SH, TNV, HFLW, CNW, HDQ, and HTT: enrolled patients, took samples and did laboratory testing.

RHVD, JJF, ERS, and MDdJ: designed the study and were involved in drafting the manuscript.

All authors have read the final manuscript and agreed with its contents.

\section{Competing interests}

This work was supported by the South East Asia Infectious Diseases Clinical Research Network. We have no competing interests.

Received: 5 October 2009

Accepted: 22 February 2010 Published: 22 February 2010

\section{References}

1. WHO: Cumulative Number of Confirmed Human Cases of Avian Influenza A/(H5N1) Reported to WHO. 2009.

2. Peiris JS, Yu WC, Leung CW, Cheung CY, Ng WF, Nicholls JM, Ng TK, Chan KH, Lai ST, Lim WL, Yuen KY, Guan Y: Re-emergence of fatal human influenza A subtype H5N1 disease. Lancet 2004, 363(9409):617-619.

3. Chen H, Smith GJ, Li KS, Wang J, Fan XH, Rayner JM, Vijaykrishna D, Zhang JX, Zhang LJ, Guo CT, Cheung CL, Xu KM, Duan L, Huang K, Qin K, Leung YH, Wu WL, Lu HR, Chen Y, Xia NS, Naipospos TS, Yuen KY, Hassan SS, Bahri S, Nguyen TD, Webster RG, Peiris JS, Guan Y: Establishment of multiple sublineages of $\mathrm{H} 5 \mathrm{~N} 1$ influenza virus in Asia: implications for pandemic control. Proc Natl Acad Sci USA 2006, 103(8):2845-2850.

4. Li KS, Guan Y, Wang J, Smith GJ, Xu KM, Duan L, Rahardjo AP, Puthavathana P, Buranathai C, Nguyen TD, Estoepangestie AT, Chaisingh A, Auewarakul P, Long HT, Hanh NT, Webby RJ, Poon LL, Chen H, Shortridge KF, Yuen KY, Webster RG, Peiris JS: Genesis of a highly pathogenic and potentially pandemic H5N1 influenza virus in eastern Asia. Nature 2004, 430(6996):209-213.

5. WHO: Evolution of H5N1 avian influenza viruses in Asia. Emerg Infect Dis 2005, 11(10):1515-1521.

6. Smith GJ, Naipospos TS, Nguyen TD, de Jong MD, Vijaykrishna D, Usman TB, Hassan SS, Nguyen TV, Dao TV, Bui NA, Leung YH, Cheung CL, Rayner JM, Zhang JX, Zhang LJ, Poon LL, Li KS, Nguyen VC, Hien TT, Farrar J, Webster RG, Chen H, Peiris JS, Guan Y: Evolution and adaptation of H5N1 influenza virus in avian and human hosts in Indonesia and Vietnam. Virology 2006, 350(2):258-268.

7. Tiensin T, Chaitaweesub P, Songserm T, Chaisingh A, Hoonsuwan W, Buranathai C, Parakamawongsa T, Premashthira S, Amonsin A, Gilbert M, Nielen M, Stegeman A: Highly pathogenic avian influenza H5N1, Thailand, 2004. Emerg Infect Dis 2005, 11(11):1664-1672.

8. Boltz DA, Douangngeun B, Sinthasak S, Phommachanh P, Rolston S, Chen H, Guan Y, Peiris JS, Smith JG, Webster RG: H5N1 influenza viruses in Lao People's Democratic Republic. Emerg Infect Dis 2006, 12(10):1593-1595.

9. WHO: Online Report: Toward a Unified Nomenclature System for Highly Pathogenic Avian Influenza Virus (H5N1). Emerg Infect Dis 2008, 14(7):e1.

10. Smith GJ, Fan XH, Wang J, Li KS, Qin K, Zhang JX, Vijaykrishna D, Cheung CL, Huang K, Rayner JM, Peiris JS, Chen H, Webster RG, Guan Y: Emergence and predominance of an $\mathrm{H} 5 \mathrm{~N} 1$ influenza variant in China. Proc Natl Acad Sci USA 2006, 103(45):16936-16941.

11. Dung NT, Vinh Nguyen T, Vijaykrishna D, Webster RG, Guan Y, Malik Peiris JS, Smith GJ: Multiple sublineages of influenza A virus (H5N1), Vietnam, 2005-2007. Emerg Infect Dis 2008, 14(4):632-636.

12. Le MT, Wertheim HF, Nguyen HD, Taylor W, Hoang PV, Vuong CD, Nguyen $H L$, Nguyen $H H$, Nguyen TQ, Nguyen TV, Van TD, Ngoc BT, Bui TN, Nguyen BG, Nguyen LT, Luong ST, Phan PH, Pham HV, Nguyen T, Fox A, Nguyen CV, Do HQ, Crusat M, Farrar J, Nguyen HT, de Jong MD, Horby P: Influenza A H5N1 clade 2.3.4 virus with a different antiviral susceptibility profile replaced clade 1 virus in humans in northern Vietnam. PLOS ONE 2008, 3(10):e3339.

13. Payungporn $S$, Phakdeewirot $P$, Chutinimitkul $S$, Theamboonlers $A$, Keawcharoen J, Oraveerakul K, Amonsin A, Poovorawan Y: Single-step multiplex reverse transcription-polymerase chain reaction (RT-PCR) for influenza A virus subtype H5N1 detection. Viral Immunol 2004, 17(4):588-593. 
14. Ng LF, Barr I, Nguyen T, Noor SM, Tan RS, Agathe LV, Gupta S, Khalii H, To TL, Hassan SS, Ren EC: Specific detection of H5N1 avian influenza A virus in field specimens by a one-step RT-PCR assay. BMC Infect Dis 2006, 6:40.

15. Payungporn S, Chutinimitkul S, Chaisingh A, Damrongwantanapokin $S$, Buranathai C, Amonsin A, Theamboonlers A, Poovorawan Y: Single step multiplex real-time RT-PCR for H5N1 influenza A virus detection. J Virol Methods 2006, 131(2):143-147.

16. WHO: Guidlines on Laboratory Diagnosis of Avian Influenza. 2007.

17. Ng EK, Cheng PK, Ng AY, Hoang TL, Lim WW: Influenza A H5N1 detection. Emerg Infect Dis 2005, 11(8):1303-1305.

18. Lu YY, Yan JY, Feng Y, Xu CP, Shi W, Mao HY: Rapid detection of H5 avian influenza virus by TaqMan-MGB real-time RT-PCR. Lett Appl Microbiol 2008, 46(1):20-25.

19. Chen W, He B, Li C, Zhang X, Wu W, Yin X, Fan B, Fan X, Wang J: Real-time RT-PCR for H5N1 avian influenza A virus detection. J Med Microbiol 2007, 56(Pt 5):603-607.

20. Ellis JS, Smith JW, Braham S, Lock M, Barlow K, Zambon MC: Design and validation of an $\mathrm{H} 5$ TaqMan real-time one-step reverse transcription-PCR and confirmatory assays for diagnosis and verification of influenza $A$ virus H5 infections in humans. J Clin Microbiol 2007, 45(5):1535-1543.

21. Braasch DA, Corey DR: Locked nucleic acid (LNA): fine-tuning the recognition of DNA and RNA. Chem Biol 2001, 8(1):1-7.

22. Ugozzoli LA, Latorra D, Puckett R, Arar K, Hamby K: Real-time genotyping with oligonucleotide probes containing locked nucleic acids. Anal Biochem 2004, 324(1):143-152.

23. Reynisson $\mathrm{E}$, Josefsen $\mathrm{MH}$, Krause M, Hoorfar J: Evaluation of probe chemistries and platforms to improve the detection limit of real-time PCR. J Microbiol Methods 2006, 66(2):206-216.

24. Higgs ES, Hayden FG, Chotpitayasunondh T, Whitworth J, Farrar J: The Southeast Asian Influenza Clinical Research Network: development and challenges for a new multilateral research endeavor. Antiviral Res 2008, 78(1):64-68.

25. CDC: New laboratory assay for diagnostic testing of avian influenza $A / H 5$ (Asian Lineage). MMWR Morb Mortal Wkly Rep 2006, 55(5):127.

26. Tran TH, Nguyen TL, Nguyen TD, Luong TS, Pham PM, Nguyen VC, Pham TS, Vo CD, Le TQ, Ngo TT, Dao BK, Le PP, Nguyen TT, Hoang TL, Cao VT, Le TG, Nguyen DT, Le HN, Nguyen KT, Le HS, Le VT, Christiane D, Tran TT, Menno de J, Schultsz C, Cheng P, Lim W, Horby P, Farrar J: Avian influenza A (H5N1) in 10 patients in Vietnam. N Engl J Med 2004, 350(12):1179-1188.

27. Buh Gasparic M, Cankar K, Zel J, Gruden K: Comparison of different realtime PCR chemistries and their suitability for detection and quantification of genetically modified organisms. BMC Biotechnol 2008, $8: 26$.

28. Thomsen R, Nielsen PS, Jensen TH: Dramatically improved RNA in situ hybridization signals using LNA-modified probes. Rna 2005, 11(11):1745-1748.

29. de Jong MD, Simmons CP, Thanh TT, Hien VM, Smith GJ, Chau TN, Hoang DM, Chau NV, Khanh TH, Dong VC, Qui PT, Cam BV, Ha do Q, Guan Y, Peiris JS, Chinh NT, Hien TT, Farrar J: Fatal outcome of human influenza A ( $\mathrm{H} 5 \mathrm{~N} 1)$ is associated with high viral load and hypercytokinemia. Nat Med 2006, 12(10):1203-1207.

30. Lee MS, Chang PC, Shien JH, Cheng MC, Shieh HK: Identification and subtyping of avian influenza viruses by reverse transcription-PCR. J Virol Methods 2001, 97(1-2):13-22.

31. Bao Y, Bolotov P, Dernovoy D, Kiryutin B, Zaslavsky L, Tatusova T, Ostell J, Lipman D: The influenza virus resource at the National Center for Biotechnology Information. J Virol 2008, 82(2):596-601.

doi:10.1186/1743-422X-7-46

Cite this article as: Tran Tan et al:: A real-time RT-PCR for detection of clade 1 and 2 H5N1 Influenza A virus using Locked Nucleic Acid (LNA) TaqMan probes. Virology Journal 2010 7:46.

\section{Submit your next manuscript to BioMed Central and take full advantage of:}

- Convenient online submission

- Thorough peer review

- No space constraints or color figure charges

- Immediate publication on acceptance

- Inclusion in PubMed, CAS, Scopus and Google Scholar

- Research which is freely available for redistribution

Submit your manuscript at www.biomedcentral.com/submit
Ciomed Central 